Article

\title{
Effect of Dietary Folic Acid Supplementation during Pregnancy on Blood Characteristics and Milk Composition of Ewes
}

\author{
Bo Wang ${ }^{1}$, Zhen Li ${ }^{1}$, Heqiong Li ${ }^{1}$, Hailing Luo ${ }^{1, *}$, Hugh T. Blair ${ }^{2,3}$, Luyang Jian ${ }^{1}$ and \\ Zhicheng Diao ${ }^{1}$ \\ 1 State Key Laboratory of Animal Nutrition, College of Animal Science and Technology, China Agricultural \\ University, Beijing 100193, China; wangboforehead@163.com (B.W.); lizhen6394@126.com (Z.L.); \\ joan374261795@163.com (H.L.); jianluyang@cau.edu.cn (L.J.); diaozhicheng@cau.edu.cn (Z.D.) \\ 2 Sheep Research Group, School of Agriculture and Environment, Massey University, Private Bag 11222, \\ Palmerston North 4442, New Zealand; h.blair@massey.ac.nz \\ 3 National Research Centre for Growth and Development, Massey University, Private Bag 11222, Palmerston \\ North 4442, New Zealand \\ * Correspondence: luohailing@cau.edu.cn; Tel.: +86-010-62734597
}

Received: 10 February 2020; Accepted: 2 March 2020; Published: 4 March 2020

Simple Summary: Folic acid (FA) plays a critical role in regulating fetal development. Cause of the association between maternal metabolism and fetal development has created interest to study FA's effects on maternal blood metabolism and milk composition. FA was supplemented in the diet of ewes with different litter size during pregnancy and blood parameters, and milk composition was monitored. The results indicated that FA supplementation improved folate metabolism balance during gestation of prolific ewes, and contributed to the ewe's blood metabolism and health. In addition, immune-related compounds in milk were improved with dietary FA supplementation, thus, the newborn lamb should benefit from the improvement in milk quality.

\begin{abstract}
The objective of the present study was to investigate the dynamic change of serum parameters and milk composition by dietary FA supplementation with ewes with different litter size from mating to lambing. The ewes were divided into six treatments (TW-CON, TW-F16, TW-F32, TR-CON, TR-F16, TR-F32) according to dietary FA levels (control, CON; 16 or $32 \mathrm{mg} \cdot \mathrm{kg}^{-1}$ rumen-protect-FA supplementation, F16 and F32) and litter size (twin born, TW; and triplet born, TR). In serum, the concentration of folate increased linearly with dietary FA supplementation $(P<0.05)$, regardless of the litter size, they showed a quadratic response to gestation progression $(P<0.05)$. With dietary FA addition, IGFI-I levels significant increased from late gestation to after lambing $(P<0.05)$, and linearly increased immunoglobulin during the perinatal period $(P<0.05)$. In colostrum and milk at $\mathrm{d} 15$, the content of folate, lactoferrin, and IgG were affected positively by FA supplementation $(P<0.05)$. IgG was higher in the TW group than TR in colostrum $(P<0.05)$, and lactoferrin in TW was lower than TR in milk of d $15(P<0.05)$. FA supplementation increased protein content in colostrum $(P<0.05)$, while it had no effect on the fat, lactose, and BUN of colostrum and milk of $\mathrm{d} 15$ $(P>0.05)$. These results suggest that FA supplementation during gestation could regulate maternal blood metabolism and contribute to milk immune composition.
\end{abstract}

Keywords: folic acid; gestation period; litter size; serum; milk composition; ewe 


\section{Introduction}

As an essential micronutrient, folic acid (FA) plays a crucial role in various metabolic processes of the cell, and it is necessary to maintain and improve fetal body development during pregnancy in humans and animals. The positive effects of FA supplementation on birth weight is well documented [1]. Its benefit for animal growth may be because adequate FA intake is required for cell division and homeostasis due to its essential role as a coenzyme in nucleic acid synthesis and repair [2,3]. FA also regulates mitochondrial biogenesis and function through changing the mitochondrial DNA content and gene expression levels to compensate tissue impairment [4]. FA contributes to increased antioxidant capacity in rats [5] and immunity in freshwater prawns [6]. Collectively, these functions suggest that FA is necessary in regulating the fetus or young animals' growth, development, and metabolism processes. We speculate that the maternal metabolism could also be modulated by dietary FA ingestion and this may affect the offspring's metabolism, especially in the early stages of growth.

Due to genetic improvement and intensification in past decades, the reproduction performance in prolific breeds of sheep and the lactation performance of cows has increased substantially. This increased performance may result in an increased demand for FA to maintain higher production. In ruminants, rumen microorganisms synthesize folate. Several studies have demonstrated that dietary FA (unprotected and protected) supplementation increased milk production, protein concentration, and milk yield of dairy cows [7-10]. The level of folates supplied by diet and ruminal microbes is not sufficient to maintain the serum folate concentrations at a constant level throughout gestation, and the decrease of serum concentrations is greater in prolific breeds from mating to 60 days of gestation of ewes [11]. Collectively, these results suggest that FA requirements are increased during gestation and lactation in high performing females.

Haematochemical parameters are good indicators of the physiological and health conditions in animals [12,13]; and the quality of milk in ewe is critical for neonatal lambs, especially for the acquisition of passive immunity [14]. Most previous studies focused on fetal growth or dam milk production, few studies have reported the effects of FA supplementation on maternal metabolism in ewes.

The aim of the present study was undertaken to determine the effect of protected dietary FA supplementation throughout the gestation period on the time-course of serum parameters from mating to lambing and milk components in prolific ewes with twin or triplet fetuses.

\section{Material and Methods}

\subsection{Animals and Experiment Design}

Procedures throughout this experiment were in accordance with the Animal Ethics Committee of Beijing. The protocol used throughout the study was approved by the Institutional Animal Care and Use Committee of the China Agricultural University (Permit number: DK996).

One hundred and twenty $\mathrm{Hu}$ sheep with similar body weights $(44.00 \pm 0.39 \mathrm{~kg})$, and multiparous ewes (all animals had given birth twice before, $24 \pm 4.2$ months of age) and showing signs of estrus were selected, and randomly divided into three treatments after mating. Ewes were housed in individual pens (size: $1.5 \times 3 \mathrm{~m}^{2}$ ) and given one of the three rations throughout the gestation period: control (no FA supplementation, CON); supplemented with $16 \mathrm{mg}$ (F16) or $32 \mathrm{mg}$ (F32) rumen-protected FA per kilogram dry matter (DM). The specific parameters of supplemented FA in this trial were the following: purity, 99.8\%; rumen passing rate and small intestinal absorption rate (measurement by rumen fistula and small intestine fistula), $92.60 \%$ and $85.59 \%$, respectively. Twenty-eight days after mating, type-B ultrasonography was used to check whether the ewes were pregnant or not. Non-pregnant ewes were removed from the groups; the litter size was not identified until lambing. After lambing, according to the litter size at birth (Twin-born, TW; Triplet-born, TR) and the ingested FA levels in diet, the ewes were divided into 6 groups $(\mathrm{TW}-\mathrm{CON} \mathrm{n}=16$, TW-F16 $\mathrm{n}=13, \mathrm{TW}-\mathrm{F} 32 \mathrm{n}=10$, TR-CON $\mathrm{n}=5$, TR-F16 $\mathrm{n}$ $=13$ and TR-F32 $\mathrm{n}=9$ ) as a $2 \times 3$ factorial design. 
The dietary component and nutrient levels were provided according to the recommendations for small ruminants of the National Research Council 2007 [15]. The percentage of DM basis of peanut vines, whole corn silage, and concentrate in total mixed ration (TMR) from early (from mating to 90 days) to late (from day 91 to lambing) gestation was $50.00: 45.00: 5.00$ and $27.00: 28.00: 45.00$, respectively. Concentrate composition and nutrient levels of TMR in the control group are shown in Table 1. Folic acid was supplemented to the total mixed ration for each of the individual ewes, the amount of TMR offered changed gradually throughout the gestation period to meet the NRC recommendation, and fed twice daily and equally at 8:00 am and 6:00 pm. The ewes had free access to drinking water throughout the experiment.

Table 1. Dietary concentrate components and nutrient levels of the basal diet (dry matter basis, \%).

\begin{tabular}{|c|c|c|c|c|c|}
\hline \multirow{2}{*}{ Ingredients } & \multicolumn{2}{|c|}{ Formula of Concentrate } & \multirow[b]{2}{*}{ Nutrients } & \multicolumn{2}{|c|}{ TMR Nutrient Levels } \\
\hline & EG & LG & & EG & LG \\
\hline Corn & 53.00 & 50.00 & Dry matter & 92.35 & 90.96 \\
\hline Soybean meal & 9.70 & 22.50 & Crude protein & 9.60 & 10.00 \\
\hline Rapeseed meal & 12.00 & 7.00 & Ether extract & 3.51 & 4.52 \\
\hline Wheat bran & 15.70 & 11.50 & Ash & 11.19 & 8.85 \\
\hline Limestone & 1.00 & 1.00 & Neutral detergent fiber & 49.19 & 34.15 \\
\hline $\mathrm{CaHPO}_{4}$ & 0.60 & 0.60 & Acid detergent fiber & 29.98 & 24.86 \\
\hline $\mathrm{NaHCO}_{3}$ & 1.30 & 1.30 & Metabolizable energy ${ }^{2)}$ & 1.93 & 2.15 \\
\hline $\mathrm{NaCl}$ & 0.80 & 0.40 & Calcium & 0.54 & 0.56 \\
\hline Vitamin E & 0.40 & 0.10 & Phosphorus & 0.37 & 0.26 \\
\hline Soybean oil & 0.30 & 0.40 & & & \\
\hline Premix ${ }^{1)}$ & 5.00 & 5.00 & & & \\
\hline De-mold agent & 0.20 & 0.20 & & & \\
\hline Total & 100.00 & 100.00 & & & \\
\hline
\end{tabular}

TMR, total mixed ration; EG, early gestation; LG, late gestation. ${ }^{1)}$ Premix provide for per kilogram TMR: VA 30000 IU, VD $10000 \mathrm{IU}, \mathrm{VE} 100 \mathrm{mg}$, Fe 90 mg, Cu 12.5 mg, Mn 50 mg, Zn 80 mg, Se 0.3 mg, I 0.8 mg, Co 0.5 mg. The premix was provided by Nongbolier Technology Co., Ltd. (Beijing, China). ${ }^{2)}$ Metabolizable energy value was calculated according to the NRC, unit: Mcal $/ \mathrm{kg}$.

\subsection{Sampling Procedure and Measurement}

\subsubsection{Dietary Chemical Analyses}

TMR samples were collected every two weeks during early (from mating to 90 days of gestation) and late (from 91days to parturition) gestation period and dried in an oven at $65^{\circ} \mathrm{C}$ for $48 \mathrm{~h}$ to obtain air-dry basis matter. Samples were then ground and passed through a sieve with opening size of $1 \mathrm{~mm}$ mesh for chemical analyses. Dry matter was measured by drying the samples in a $105^{\circ} \mathrm{C}$ oven for $2 \mathrm{~h}$, content of ash was assessed by burning the samples in a $550{ }^{\circ} \mathrm{C}$ muffle furnace until reaching a constant weight. Crude protein was determined by nitrogen content (measured by macro-Kjeldahl method) multiplied by 6.25 [16]. A reflux system (ANKOM XT15, Ankom Technology, Macedon, NY, USA) with petroleum ether was performed for 1 hour at $90^{\circ} \mathrm{C}$ to detect the ether extract content in diets. Neutral and acid detergent fiber in the diets were measured following the methods as described by Van Soest et al. [17]. An atomic absorption spectrometer (Czerny-Turner AAS8000, Skyray Instruments, Dallas, TX, USA) was used to determine the content of calcium and the molybdenum blue colorimetric method was performed to measure the phosphorus content [16].

\subsubsection{Serum Parameters}

Blood samples were collected from the jugular vein through a $10 \mathrm{~mL}$ vacuum tube in the morning before feeding at day 1, 30, 90, 140 of pregnancy and the first day after parturition. The serum samples were separated by centrifugation of blood and stored at $-20^{\circ} \mathrm{C}$ for determination of serum variables. The concentration of folate, homocysteine (Hcy), insulin-like growth factor-I (IGF-I), and growth hormone $(\mathrm{GH})$ were determined using a sheep enzyme-linked immunosorbent assay (ELISA) 
commercial kit (DuMa Biological Technology Development Co., Ltd., Shanghai, China), following the manufacturer's instructions. The content of immunoglobulin (IgG, IgM, IgA) in the serum were detected by a KHB-1280 automatic biochemical analyzer (KeHua Bio-engineering Co., Ltd., Shanghai, China).

\subsubsection{Milk Composition}

Colostrum samples were collected at 12 and $36 \mathrm{~h}$ after lambing, and preserved with 2-bromo-2-nitropropane-1, 3-diol. The two samples were sub-sampled and mixed together proportionately to each sample weight for milk composition determination. Milk samples were taken in the morning of days 14,15, and 16 after parturition, and mixed proportionately as for the milk samples of day 15. The milk samples were preserved the same as colostrum. Concentrations of folate and lactoferrin in the colostrum and milk were measured following the instruction of a sheep enzyme-linked immunosorbent assay (ELISA) commercial kit (DuMa Biological Technology Development Co., Ltd., Shanghai, China). IgG content in the colostrum and normal milk were conducted as the manufacturer's instruction of the ELISA commercial kit (DuMa Biological Technology Development Co., Ltd., Shanghai, China). The content of protein, fat, lactose, and BUN in the colostrum and normal milk were detected by milk analyzer (Milko-Scan FT +, Foss Electric, Hillerød, Denmark).

\subsection{Statistical Analysis}

Indices of blood and milk were analyzed using the generalized liner model (GLM) procedure of SPSS version 22.0 (SPSS, IBM, Inc., Chicago, USA) to assess the main effects of litter size (TW and TR) and the FA levels (CON, F16 and F32), and the interaction effects between the litter size and FA levels. Statistical significance of the main effect was demonstrated at a level of $P<0.05$. The time-course effect (from mating to lambing) of folate, Hcy, IGF-I, and GH in the serum of each treatment was analyzed by generalized linear mixed model (GLMM) using SPSS. Polynomial analysis was performed to test the linear or quadratic response of variables to the dietary FA levels or the time-course effect.

\section{Results}

\subsection{Serum Variables from Gestation to Parturition}

\subsubsection{Folate and Hcy}

No significant interaction effects (litter size $\times$ FA levels) on serum folate and Hcy concentrations were found in this experiment $(P>0.05$; Table 2$)$. The serum folate concentration was higher in the TW group than TR only at 90 days after mating $(P<0.05)$, while the concentration showed a significant linear increase with dietary FA supplementation at 1, 30, 90, and 140 days of gestation and after lambing $(P<0.05)$. For the time-course effect, serum folate concentrations in the six treatments exhibited a quadratic response throughout the gestation period, while decreasing from mating to the lowest point at 90 days of pregnancy, and then increasing until parturition $(P<0.05$, Figure $1 \mathrm{~A})$.

No significant difference was found between the TW and TR group on Hcy concentrations on the 30th, 90th, and 140th day of pregnancy and after lambing $(P>0.05)$. Concentrations of Hcy decreased linearly with FA addition in the diets $(P<0.05$; Table 2$)$. Concentrations of Hcy were non-significant throughout gestation in each of the 6 treatments $(P>0.05$; Figure $1 \mathrm{~B})$. 
Table 2. Folate and Hcy concentrations in the serum from mating to parturition.

\begin{tabular}{|c|c|c|c|c|c|c|c|c|c|c|c|c|}
\hline \multirow{2}{*}{ Item } & \multirow{2}{*}{$\begin{array}{l}\text { Time } \\
\text { (d) }\end{array}$} & \multicolumn{2}{|c|}{$\mathbf{L Z}$} & \multicolumn{3}{|c|}{ D } & \multirow{2}{*}{ SEM } & \multicolumn{5}{|c|}{$P$-Values } \\
\hline & & TW & TR & CON & F16 & F32 & & LZ & D & $\mathbf{I} \times$ & $\mathbf{L}$ & $\mathbf{Q}$ \\
\hline \multirow{5}{*}{$\begin{array}{l}\text { Folate } \\
(\mathrm{ng} / \mathrm{ml})\end{array}$} & 1 & 18.11 & 18.67 & $14.51^{\mathrm{c}}$ & $18.09^{b}$ & $22.57^{a}$ & 0.63 & 0.325 & $<0.001$ & 0.889 & $<0.001$ & 0.378 \\
\hline & 30 & 17.19 & 17.23 & $13.35^{c}$ & $17.24^{b}$ & $21.04^{\mathrm{a}}$ & 0.58 & 0.923 & $<0.001$ & 0.896 & $<0.001$ & 0.895 \\
\hline & 90 & 14.7 & 13.87 & $10.88^{c}$ & $14.86^{\mathrm{b}}$ & $17.11^{\mathrm{a}}$ & 0.46 & 0.01 & $<0.001$ & 0.91 & $<0.001$ & 0.019 \\
\hline & 140 & 17.44 & 17.97 & $14.25^{c}$ & $18.52^{b}$ & $20.35^{a}$ & 0.5 & 0.241 & $<0.001$ & 0.967 & $<0.001$ & 0.006 \\
\hline & $\mathrm{P}$ & 18.7 & 19.35 & $15.70^{c}$ & $19.90^{\mathrm{b}}$ & $21.48^{\mathrm{a}}$ & 0.48 & 0.23 & $<0.001$ & 0.984 & $<0.001$ & 0.017 \\
\hline \multirow{4}{*}{$\begin{array}{c}\text { Hcy } \\
(\mu \mathrm{mol} / \mathrm{L})\end{array}$} & 30 & 6.98 & 7.04 & $8.48^{a}$ & $6.24^{b}$ & $6.31^{b}$ & 0.24 & 0.857 & $<0.001$ & 0.746 & $<0.001$ & 0.008 \\
\hline & 90 & 7.48 & 7.96 & $9.12^{\mathrm{a}}$ & $7.13^{b}$ & $6.91^{\mathrm{b}}$ & 0.23 & 0.171 & $<0.001$ & 0.855 & $<0.001$ & 0.018 \\
\hline & 140 & 6.88 & 7.03 & $7.91^{\mathrm{a}}$ & $6.61^{b}$ & $6.34^{\mathrm{b}}$ & 0.16 & 0.555 & $<0.001$ & 0.986 & $<0.001$ & 0.048 \\
\hline & $\mathrm{P}$ & 8.04 & 8.22 & $9.89^{a}$ & $7.46^{\mathrm{b}}$ & $7.04^{b}$ & 0.27 & 0.62 & $<0.001$ & 0.972 & $<0.001$ & 0.007 \\
\hline
\end{tabular}

Hcy, homocysteine; LZ, litter size; D, diet; TW, twin born; TR, triplet born; CON, control group; F16 and F32, 16 or $32 \mathrm{mg} \cdot(\mathrm{kg} . \mathrm{DM})^{-1} \mathrm{FA}$ supplemented in the basal diets, respectively; $\mathrm{I} \times$, interaction effect; $\mathrm{L}, P$ value of liner effect; $\mathrm{Q}$, $P$ value of quadratic effect; SEM, standard error of mean; $P$, postpartum. Different superscripts in the same row means significant difference.
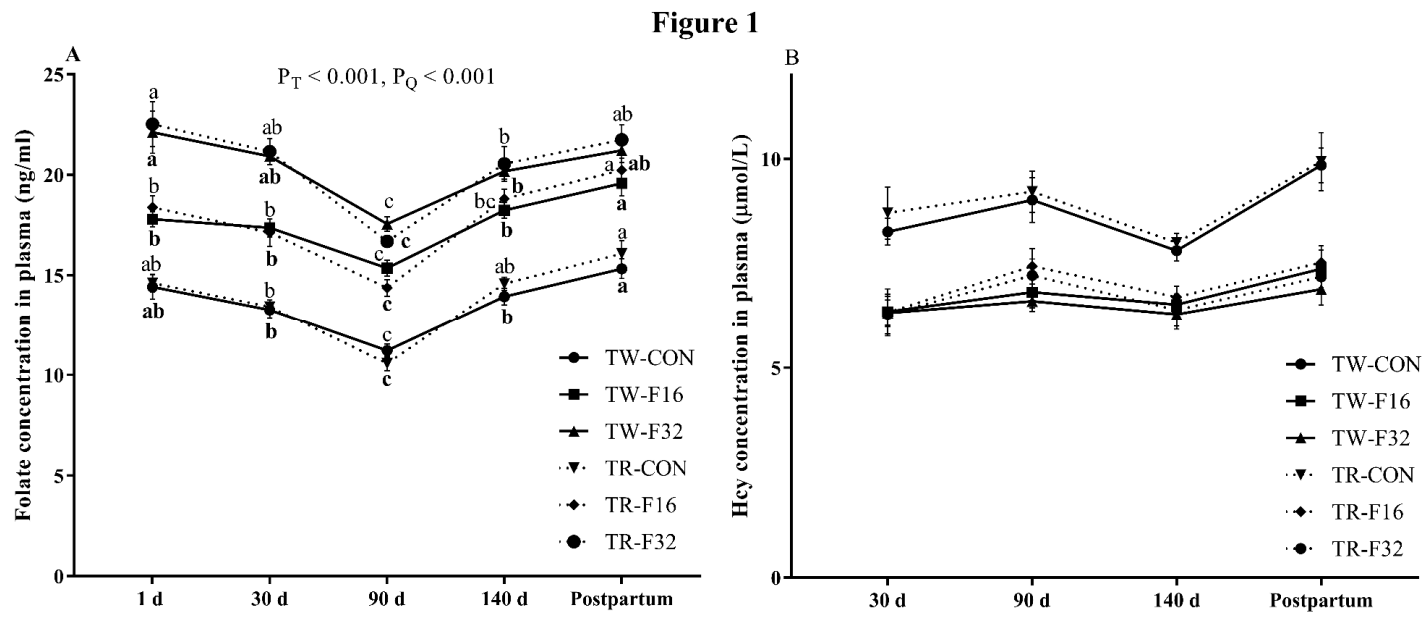

Figure 1. Folate (A) and Hcy (B) concentration in serum. Data are means \pm SEM. Hcy, homocysteine; TW-CON, TW-F16 and TW-F32, twins born from ewes fed 0, 16, or $32 \mathrm{mg} \cdot(\mathrm{kg} . \mathrm{DM})^{-1} \mathrm{FA}$ in the basal diet, respectively; TR-CON, TR-F16 and TR-F32, triplets born from ewes fed 0, 16, or $32 \mathrm{mg} \cdot(\mathrm{kg} . \mathrm{DM})^{-1}$ FA in the basal diet, respectively. $P_{\mathrm{T}}, P$ value of time effect; $P_{\mathrm{Q}}, P$ value of quadratic effect. Different lowercases indicated significance of corresponding TR groups (dotted line); different bold lowercases indicated significance of corresponding TW groups (full line). $\mathrm{N}=5$ for TR-CON, and $\mathrm{n}=6$ for other groups.

\subsubsection{IGF-I and GH}

Concentration of IGF-I and GH in the serum did not differ significantly between TW and TR groups throughout the gestation period ( $P>0.05$; Table 3$)$. On the 90th of gestation and after lambing, IGF-I levels increased linearly with dietary FA supplementation $(P<0.05$; Table 3$)$; with FA supplementation in the TR groups (TR-F16 and TR-F32), the IGF-I also indicated a linear increase with the progression of pregnancy $(P<0.05)$, but did not change significantly in other treatments $(P>0.05$; Table 4$)$. The concentration of $\mathrm{GH}$ at different time among the treatments was not affected by litter size and dietary FA levels $(P>0.05$; Table 3$)$, while the concentration increased linearly as gestation progressed until lambing $(P<0.05$; Table 4$)$. 
Table 3. The concentrations of IGF-I and GH affected by litter size and dietary FA levels (ng/mL).

\begin{tabular}{|c|c|c|c|c|c|c|c|c|c|c|c|c|}
\hline \multirow{2}{*}{ Item } & \multirow{2}{*}{$\begin{array}{l}\text { Time } \\
\text { (d) }\end{array}$} & \multicolumn{2}{|c|}{ LZ } & \multicolumn{3}{|c|}{ D } & \multirow{2}{*}{ SEM } & \multicolumn{5}{|c|}{$P$-Values } \\
\hline & & TW & TR & $\mathrm{CON}$ & F16 & F32 & & $\mathbf{L Z}$ & D & $\mathbf{I} \times$ & L & $\mathbf{Q}$ \\
\hline \multirow{4}{*}{ IGF-I } & 30 & 242.59 & 248.17 & 241.25 & 252.52 & 242.37 & 4.64 & 0.592 & 0.619 & 0.94 & 0.87 & 0.328 \\
\hline & 90 & 263.55 & 273.01 & $252.68^{b}$ & $276.12^{\mathrm{a}}$ & $275.99^{a}$ & 3 & 0.053 & $<0.001$ & 0.611 & 0.001 & 0.023 \\
\hline & 140 & 246.7 & 256.96 & 237.17 & 258.23 & 260.09 & 4.25 & 0.225 & 0.076 & 0.897 & 0.023 & 0.215 \\
\hline & $\mathrm{P}$ & 265.57 & 272.84 & $255.93^{b}$ & $278.24^{\mathrm{a}}$ & $273.43^{\mathrm{a}}$ & 3.55 & 0.284 & 0.035 & 0.54 & 0.046 & 0.058 \\
\hline \multirow{4}{*}{ GH } & 30 & 10.41 & 10.33 & 10.39 & 10.2 & 10.53 & 0.22 & 0.876 & 0.846 & 0.924 & 0.571 & 0.691 \\
\hline & 90 & 12.12 & 12.46 & 11.82 & 12.4 & 12.66 & 0.17 & 0.324 & 0.151 & 0.493 & 0.035 & 0.56 \\
\hline & 140 & 12.12 & 12.29 & 11.97 & 12.44 & 12.21 & 0.2 & 0.673 & 0.655 & 0.304 & 0.44 & 0.307 \\
\hline & $\mathrm{P}$ & 13.19 & 13.52 & 12.57 & 13.98 & 13.51 & 0.23 & 0.482 & 0.061 & 0.843 & 0.092 & 0.044 \\
\hline
\end{tabular}

IGF-I, insulin-like growth factor-I; GH, growth hormone; LZ, litter size; D, diet; TW, twin born; TR, triplet born; CON, control group; F16 and F32, 16 or $32 \mathrm{mg} \cdot(\mathrm{kg} . \mathrm{DM})^{-1}$ FA supplemented in the basal diet, respectively; I $\times$, interaction effect; $L, P$ value of liner effect; $Q, P$ value of quadratic effect; $S E M$, standard error of mean; $P$, postpartum. Different superscripts in the same row means significant difference.

Table 4. The change of IGF-I and GH in serum over time of pregnancy $(\mathrm{ng} / \mathrm{mL})$.

\begin{tabular}{|c|c|c|c|c|c|c|c|c|c|}
\hline \multirow{2}{*}{ Item } & \multirow{2}{*}{ Groups } & \multicolumn{4}{|c|}{ Time (d) } & \multirow{2}{*}{ SEM } & \multicolumn{3}{|c|}{$P$-Values } \\
\hline & & 30 & 90 & 140 & $\mathbf{P}$ & & $\mathbf{T}$ & $\mathbf{L}$ & $\mathbf{Q}$ \\
\hline \multirow{6}{*}{ IGF-I } & TW-CON & 239.09 & 250.93 & 233.4 & 257.83 & 5.45 & 0.414 & 0.447 & 0.571 \\
\hline & TW-F16 & 247.34 & 271.3 & 250.51 & 271.66 & 4.48 & 0.082 & 0.168 & 0.865 \\
\hline & TW-F32 & 241.33 & 268.41 & 256.2 & 267.2 & 4.83 & 0.175 & 0.127 & 0.391 \\
\hline & TR-CON & 243.4 & 254.42 & 240.94 & 254.02 & 5.87 & 0.83 & 0.758 & 0.938 \\
\hline & TR-F16 & $257.70^{b}$ & $281.04^{\mathrm{a}}$ & $265.94^{a b}$ & $284.83^{a}$ & 3.76 & 0.034 & 0.043 & 0.737 \\
\hline & TR-F32 & $243.39^{b}$ & $283.57^{a}$ & $263.98^{a b}$ & $279.66^{a}$ & 4.83 & 0.003 & 0.012 & 0.111 \\
\hline \multirow{6}{*}{ GH } & TW-CON & 10.54 & 11.45 & 11.51 & 12.43 & 0.27 & 0.109 & 0.02 & 0.977 \\
\hline & TW-F16 & $10.12^{c}$ & $12.15^{b}$ & $12.28^{b}$ & $13.66^{a}$ & 0.33 & $<0.001$ & $<0.001$ & 0.447 \\
\hline & TW-F32 & $10.57^{b}$ & $12.76^{\mathrm{a}}$ & $12.56^{\mathrm{a}}$ & $13.49^{\mathrm{a}}$ & 0.32 & 0.003 & 0.001 & 0.199 \\
\hline & TR-CON & $10.22^{b}$ & $12.19^{\mathrm{a}}$ & $12.42^{\mathrm{a}}$ & $12.71^{\mathrm{a}}$ & 0.34 & 0.03 & 0.007 & 0.132 \\
\hline & TR-F16 & $10.28^{c}$ & $12.65^{b}$ & $12.59^{b}$ & $14.31^{\mathrm{a}}$ & 0.37 & 0.001 & $<0.001$ & 0.54 \\
\hline & TR-F32 & $10.49^{b}$ & $12.55^{\mathrm{a}}$ & $11.86^{\mathrm{ab}}$ & $13.53^{a}$ & 0.36 & 0.01 & 0.004 & 0.744 \\
\hline
\end{tabular}

IGF-I, insulin-like growth factor-I; GH, growth hormone; P, postpartum; SEM, standard error of mean; T, time effect; L, $P$ value of liner effect; $Q, P$ value of quadratic effect. TW-CON, TW-F16 and TW-F32, ewes lambing twins and fed 0, 16, or $32 \mathrm{mg} \cdot(\mathrm{kg} . \mathrm{DM})^{-1}$ FA in the basal diet, respectively; TR-CON, TR-F16 and TR-F32, ewes lambing triplets and fed 0,16 , or $32 \mathrm{mg} \cdot(\mathrm{kg} . \mathrm{DM})^{-1} \mathrm{FA}$ in the basal diet, respectively. $\mathrm{N}=5$ for TR-CON, and $\mathrm{n}=6$ for other treatments. Different superscripts in the same row means significant difference.

\subsubsection{Immunoglobulin}

Compared with ewes ingested control diet, IgG content increased linearly with FA supplementation in the diet at 140 days of pregnancy and after lambing $(P<0.05)$; and postpartum IgG showed a higher level in the TR group than TW $(P<0.05$; Table 5$)$. Either in the TW or TR group, IgG concentration indicated a linear increase from mating to laming with dietary FA supplementation $(P<0.05)$, while no significance was found in ewes the fed control diet $(P>0.05$; Table 6). Concentrations of IgM and IgA only exhibited a linear increase after lambing in the ewes whose diet was supplemented with FA $(P<0.05)$ (Table 5). From 30 days after pregnancy to lambing, the concentrations of IgM exhibited a linear increase in the TR groups with FA supplementation $(P<0.05)$, but the levels in others treatments stand in the same line throughout the experiment $(P>0.05)$. Concentrations of $\operatorname{IgA}$ were not significantly different in each of the treatments throughout gestation until lambing $(P>0.05$; Table 6$)$. 
Table 5. Serum immunoglobulin concentration influenced by litter size and dietary FA levels (g/L).

\begin{tabular}{|c|c|c|c|c|c|c|c|c|c|c|c|c|}
\hline \multirow{2}{*}{ Item } & \multirow{2}{*}{$\begin{array}{c}\text { Time } \\
\text { (d) }\end{array}$} & \multicolumn{2}{|c|}{$\mathbf{L Z}$} & \multicolumn{3}{|c|}{ D } & \multirow{2}{*}{ SEM } & \multicolumn{5}{|c|}{$P$-Values } \\
\hline & & TW & TR & $\mathrm{CON}$ & F16 & F32 & & LZ & D & $I \times$ & $\mathbf{L}$ & $\mathbf{Q}$ \\
\hline \multirow{4}{*}{ IgG } & 30 & 10.95 & 11 & 11.01 & 11.3 & 10.61 & 0.22 & 0.91 & 0.442 & 0.526 & 0.597 & 0.192 \\
\hline & 90 & 11.94 & 11.91 & 12.16 & 11.9 & 11.71 & 0.21 & 0.944 & 0.74 & 0.897 & 0.422 & 0.944 \\
\hline & 140 & 11.74 & 12.25 & $10.42^{b}$ & $12.68^{a}$ & $12.88^{a}$ & 0.28 & 0.237 & 0.002 & 0.219 & $<0.001$ & 0.033 \\
\hline & $\mathrm{P}$ & 13.46 & 14.48 & $12.20^{b}$ & $14.98^{\mathrm{a}}$ & $14.73^{a}$ & 0.32 & 0.033 & $<0.001$ & 0.303 & 0.001 & 0.006 \\
\hline \multirow{4}{*}{ IgM } & 30 & 1.61 & 1.57 & 1.57 & 1.57 & 1.64 & 0.03 & 0.524 & 0.524 & 0.925 & 0.394 & 0.532 \\
\hline & 90 & 1.58 & 1.6 & 1.56 & 1.59 & 1.64 & 0.03 & 0.696 & 0.46 & 0.457 & 0.25 & 0.843 \\
\hline & 140 & 1.63 & 1.64 & 1.64 & 1.62 & 1.64 & 0.03 & 0.917 & 0.963 & 0.979 & 0.919 & 0.762 \\
\hline & $\mathrm{P}$ & 1.73 & 1.77 & $1.62^{b}$ & $1.83^{a}$ & $1.80^{a}$ & 0.03 & 0.459 & 0.023 & 0.517 & 0.025 & 0.058 \\
\hline \multirow{4}{*}{ IgA } & 30 & 0.45 & 0.44 & 0.43 & 0.45 & 0.45 & 0.02 & 0.849 & 0.689 & 0.845 & 0.543 & 0.594 \\
\hline & 90 & 0.43 & 0.43 & 0.41 & 0.45 & 0.43 & 0.01 & 0.988 & 0.345 & 0.964 & 0.323 & 0.229 \\
\hline & 140 & 0.45 & 0.44 & 0.42 & 0.46 & 0.46 & 0.01 & 0.856 & 0.087 & 0.879 & 0.035 & 0.337 \\
\hline & $\mathrm{P}$ & 0.43 & 0.43 & $0.41^{\mathrm{b}}$ & $0.44^{\mathrm{a}}$ & $0.44^{\mathrm{a}}$ & 0.01 & 0.9 & 0.049 & 0.95 & 0.015 & 0.225 \\
\hline
\end{tabular}

IgG, immunoglobulin G; IgM, immunoglobulin M; IgA, immunoglobulin A; LZ, litter size; D, diet; TW, twin born; TR, triplet born; CON, control group; F16 and F32, 16 or $32 \mathrm{mg} \cdot(\mathrm{kg} . \mathrm{DM})^{-1}$ FA supplemented in the basal diet, respectively. I $\times$, interaction effect; $L, P$ value of liner effect; $Q, P$ value of quadratic effect; SEM, standard error of mean; IgG, IgM and IgA, immunoglobulin G, M and A; P, postpartum. Different superscripts in the same row means significant difference.

Table 6. Variance of immunoglobulin in serum from 30 days after mating to parturition $(\mathrm{g} / \mathrm{L})$.

\begin{tabular}{|c|c|c|c|c|c|c|c|c|c|}
\hline \multirow{2}{*}{ Item } & \multirow{2}{*}{ Groups } & \multicolumn{4}{|c|}{ Time (d) } & \multirow{2}{*}{ SEM } & \multicolumn{3}{|c|}{$P$-Values } \\
\hline & & 30 & 90 & 140 & $\mathbf{P}$ & & $\mathbf{T}$ & $\mathbf{L}$ & $\mathbf{Q}$ \\
\hline \multirow{6}{*}{ IgG } & TW-CON & 10.67 & 12.13 & 10.67 & 12.22 & 0.3 & 0.089 & 0.217 & 0.934 \\
\hline & TW-F16 & $11.62^{b}$ & $11.83^{b}$ & $12.4^{\mathrm{b}}$ & $14.26^{\mathrm{a}}$ & 0.32 & 0.005 & 0.001 & 0.11 \\
\hline & TW-F32 & $10.55^{b}$ & $11.88^{b}$ & $12.14^{b}$ & $13.92^{\mathrm{a}}$ & 0.37 & 0.004 & 0.001 & 0.691 \\
\hline & TR-CON & 11.35 & 12.2 & 10.18 & 12.17 & 0.35 & 0.156 & 0.876 & 0.388 \\
\hline & TR-F16 & $10.98^{c}$ & $11.98^{b c}$ & $12.96^{b}$ & $15.71^{\mathrm{a}}$ & 0.45 & $<0.001$ & $<0.001$ & 0.105 \\
\hline & TR-F32 & $10.66^{c}$ & $11.55^{c}$ & $13.62^{b}$ & $15.55^{\mathrm{a}}$ & 0.48 & $<0.001$ & $<0.001$ & 0.345 \\
\hline \multirow{6}{*}{ IgM } & TW-CON & 1.6 & 1.59 & 1.65 & 1.65 & 0.03 & 0.893 & 0.522 & 0.995 \\
\hline & TW-F16 & 1.6 & 1.54 & 1.61 & 1.77 & 0.04 & 0.143 & 0.073 & 0.131 \\
\hline & TW-F32 & 1.65 & 1.62 & 1.63 & 1.77 & 0.04 & 0.626 & 0.378 & 0.382 \\
\hline & TR-CON & 1.55 & 1.52 & 1.64 & 1.6 & 0.03 & 0.691 & 0.455 & 0.937 \\
\hline & TR-F16 & $1.53^{b}$ & $1.64^{b}$ & $1.63^{b}$ & $1.89^{\mathrm{a}}$ & 0.04 & 0.01 & 0.003 & 0.268 \\
\hline & TR-F32 & 1.64 & 1.66 & 1.64 & 1.83 & 0.03 & 0.1 & 0.046 & 0.185 \\
\hline \multirow{6}{*}{$\operatorname{Ig} A$} & TW-CON & 0.44 & 0.42 & 0.43 & 0.41 & 0.01 & 0.687 & 0.338 & 0.912 \\
\hline & TW-F16 & 0.45 & 0.45 & 0.46 & 0.44 & 0.01 & 0.838 & 0.837 & 0.566 \\
\hline & TW-F32 & 0.45 & 0.43 & 0.46 & 0.44 & 0.01 & 0.688 & 0.826 & 0.986 \\
\hline & TR-CON & 0.42 & 0.41 & 0.41 & 0.41 & 0.02 & 0.691 & 0.455 & 0.937 \\
\hline & TR-F16 & 0.46 & 0.45 & 0.46 & 0.44 & 0.01 & 0.843 & 0.526 & 0.849 \\
\hline & TR-F32 & 0.44 & 0.44 & 0.47 & 0.44 & 0.01 & 0.769 & 0.787 & 0.668 \\
\hline
\end{tabular}

IgG, immunoglobulin G; IgM, immunoglobulin M; IgA, immunoglobulin A. P, postpartum; SEM, standard error of mean; T, time effect; L, liner effect; $Q$, quadratic effect. TW-CON, TW-F16 and TW-F32, ewes lambing twins and fed 0, 16, or $32 \mathrm{mg} \cdot(\mathrm{kg} . \mathrm{DM})^{-1} \mathrm{FA}$ in the basal diet, respectively; TR-CON, TR-F16 and TR-F32, ewes lambing triplets and fed 0,16 , or $32 \mathrm{mg} \cdot(\mathrm{kg} . \mathrm{DM})^{-1} \mathrm{FA}$ in the basal diet, respectively. IgG, IgM and IgA, immunoglobulin G, M and A. N $=5$ for TR-CON, and $n=6$ for other treatments. Different superscripts in the same row means significant difference.

\subsection{Milk Components}

\subsubsection{Folate, IgG and Lactoferrin Concentrations}

Folate concentrations in both colostrum and milk of the 15th day were not influenced by litter size $(P>0.05$; Figure 2A), but it increased linearly in colostrum in response to dietary FA supplementation, and a similar tendency was found at milk from the 15th day $(P<0.05$; Figure $2 \mathrm{~B})$. The colostrum $\operatorname{IgG}$ content showed a higher level in TW than that in TR group $(P<0.05$; Figure 3A), whereas no difference was observed in milk after at 15 days of lambing $(P>0.05$; Figure $3 C)$. Dietary FA supplementation also linearly increased the IgG levels in the colostrum and the 15th days milk $(P<0.05)$ (Figure 3B,D). 
Lactoferrin content in colostrum was not affected by litter size $(P>0.05)$. However, it showed a higher level in TR group when compared with its content in TW at 15 days after lambing $(P<0.05$; Figure $4 \mathrm{~A})$. The concentration of lactoferrin increased in both colostrum and milk on the 15th day in response to the FA supplemented in diets $(P<0.05$; Figure 4B).

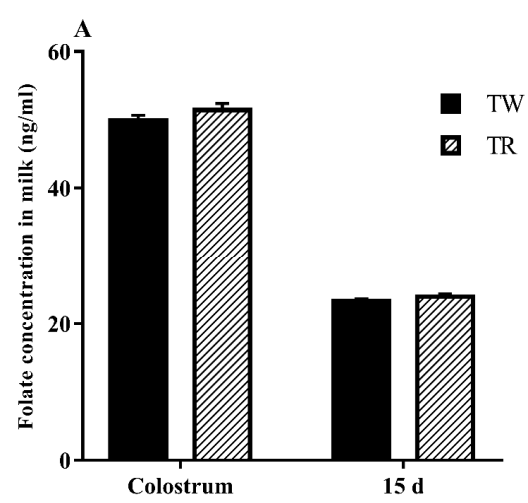

Figure 2

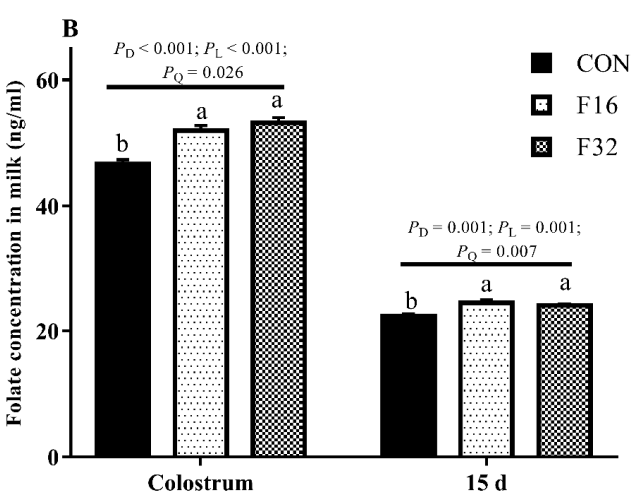

Figure 2. Effect of litter size (A) and FA levels (B) on the folate concentrations in milk. Data are means \pm SEM. TW, twin born; TR, triplet born; CON, F16 and F32, ewes fed 0, 16, or $32 \mathrm{mg} \cdot(\mathrm{kg} . \mathrm{DM})^{-1} \mathrm{FA}$ in the basal diet, respectively. $P_{\mathrm{D}}, P$ value of diet FA supplementation; $P_{\mathrm{L}}, P$ value of liner effect; $P_{\mathrm{Q}}, P$ value of quadratic effect.

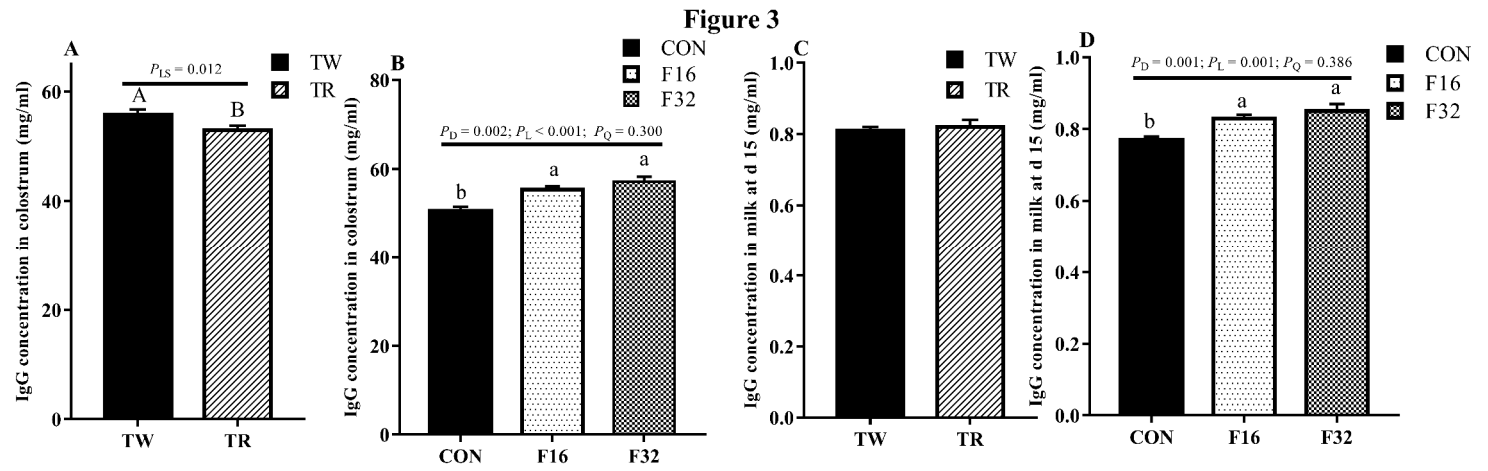

Figure 3. IgG concentrations affected by litter size $(\mathbf{A}, \mathbf{C})$ and dietary FA levels $(\mathbf{B}, \mathbf{D})$ in milk. Data are means \pm SEM. TW, twin born; TR, triplet born; CON, F16 and F32, ewes fed 0, 16, or 32 mg.(kg.DM) ${ }^{-1}$ FA in the basal diet, respectively. $P_{\mathrm{LS}}, P$ value of litter size; $P_{\mathrm{D}}, P$ value of diet FA supplementation; $P_{\mathrm{L}}$, $P$ value of liner effect; $P_{\mathrm{Q}}, P$ value of quadratic effect. 

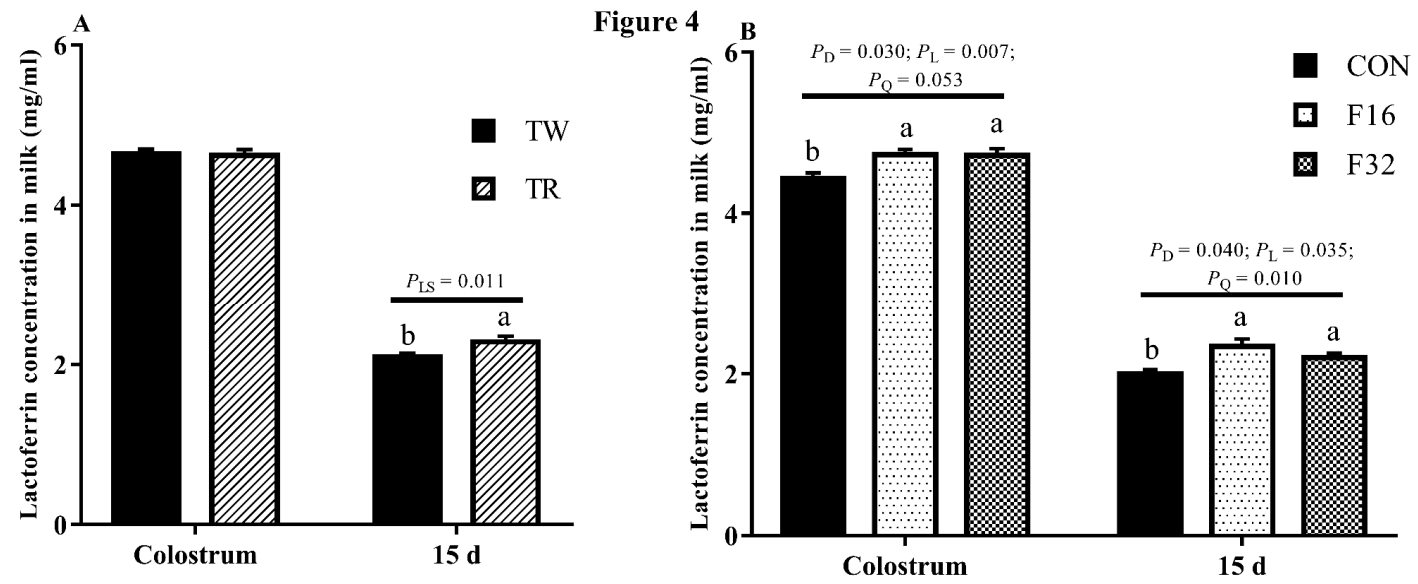

Figure 4. The concentration of lactoferrin influenced by litter size (A) and FA levels (B) in milk. Data are means \pm SEM. TW, twin born; TR, triplet born; CON, F16 and F32, ewes fed 0, 16, or 32 mg.(kg.DM) ${ }^{-1}$ FA in the basal diet, respectively. $P_{\mathrm{LS}}, P$ value of litter size; $P_{\mathrm{D}}, P$ value of diet FA supplementation; $P_{\mathrm{L}}$, $P$ value of liner effect; $P_{\mathrm{Q}}, P$ value of quadratic effect.

\subsubsection{Colostrum and Normal Milk Composition}

In both colostrum and the milk at 15 days after parturition, the FA levels and litter size show no significant influence on the concentrations of fat, lactose and BUN $(P>0.05$; Table 7). Whereas protein content increased linearly $(P<0.05)$ in colostrum with maternal diet FA supplementation, and it still tended to be higher from the 15th day's milk from ewes with FA supplemented during gestation period than the milk form ewes fed the control diet $(P=0.098)$.

Table 7. Components of colostrum and normal milk.

\begin{tabular}{|c|c|c|c|c|c|c|c|c|c|c|c|c|}
\hline \multirow{2}{*}{ Items } & \multirow{2}{*}{ Time } & \multicolumn{2}{|c|}{ LZ } & \multicolumn{3}{|c|}{ D } & \multirow{2}{*}{ SEM } & \multicolumn{5}{|c|}{$P$-Values } \\
\hline & & TW & TR & CON & F16 & F32 & & LZ & D & $\mathbf{I} \times$ & $\mathbf{L}$ & $\mathbf{Q}$ \\
\hline Fat & C & 12.06 & 11.92 & 11.47 & 12.15 & 12.24 & 0.27 & 0.645 & 0.570 & 0.978 & 0.287 & 0.609 \\
\hline$(\%)$ & $15 \mathrm{~d}$ & 5.27 & 5.48 & 4.89 & 5.52 & 5.70 & 0.19 & 0.671 & 0.218 & 0.968 & 0.076 & 0.569 \\
\hline \multirow{2}{*}{$\begin{array}{l}\text { Protein } \\
(\%)\end{array}$} & $C$ & 13.46 & 13.23 & $12.68^{b}$ & $13.72^{a}$ & $13.64^{a}$ & 0.16 & 0.497 & 0.046 & 0.865 & 0.031 & 0.096 \\
\hline & $15 \mathrm{~d}$ & 5.59 & 5.47 & 5.26 & 5.66 & 5.67 & 0.10 & 0.496 & 0.098 & 0.845 & 0.042 & 0.242 \\
\hline \multirow{2}{*}{$\begin{array}{l}\text { Lactose } \\
(\%)\end{array}$} & $\mathrm{C}$ & 3.15 & 3.27 & 3.16 & 3.21 & 3.26 & 0.12 & 0.678 & 0.963 & 0.836 & 0.578 & 0.869 \\
\hline & $15 \mathrm{~d}$ & 5.67 & 5.52 & 5.49 & 5.69 & 5.61 & 0.04 & 0.053 & 0.110 & 0.792 & 0.240 & 0.096 \\
\hline \multirow{2}{*}{$\begin{array}{l}\text { BUN } \\
(\mathrm{mg} / \mathrm{dL})\end{array}$} & C & 4.81 & 4.74 & 4.91 & 4.71 & 4.71 & 0.38 & 0.693 & 0.619 & 0.955 & 0.313 & 0.512 \\
\hline & $15 \mathrm{~d}$ & 5.84 & 5.88 & 6.16 & 5.64 & 5.79 & 0.16 & 0.911 & 0.468 & 0.874 & 0.231 & 0.274 \\
\hline
\end{tabular}

TW, twin born; TR, triplet born; CON, control group; F16 and F32, 16 or $32 \mathrm{mg} \cdot(\mathrm{kg} . \mathrm{DM})^{-1}$ FA supplemented in the basal diet, respectively; $\mathrm{LZ}$, litter size; $\mathrm{D}$, diet; $\mathrm{I} \times$, interaction effect; $\mathrm{L}, P$ value of liner effect; $\mathrm{Q}, P$ value of quadratic effect; SEM, standard error of mean; $C$, colostrum; BUN, blood urea nitrogen. $N=5$ for TR-CON, and $n=6$ for other treatments. Different superscripts in the same row means significant difference.

\section{Discussion}

Serum folate concentration is an accurate indicator of the status of body folate [18]. In the present study, serum concentration of folate increased linearly with dietary FA supplementation throughout the experiment, which is consistent with previous studies in dairy cows $[10,19,20]$ and sheep [21]. The folate concentration was higher in twin born ewes than triplet born ewes at 90 days after mating, this may be due to the higher folate requirement as gestation progressed with larger litter size from mating to early gestation. The result is similar to a previous report that serum folate concentration decreased more between mating and $60 \mathrm{~d}$ of gestation in prolific sheep breeds than for non-prolific breeds [11]. Regardless of dietary FA supplementation, we found the pattern of serum folate concentration had the same trend from mating to lambing, decreasing from mating to the beginning of late gestation 
period, then increasing until laming. These changes may be related to the increased requirement of FA in early gestation for embryo development and fetus organ formation, and then decreased fetal requirement after organ formation in late gestation. Similarly, Girard et al. (1996) reported that folate concentration of ewes from different breeds with different litter size showed a quadratic response to time to pregnancy (from mating to $140 \mathrm{~d}$ of gestation) [11]. The lowest folate content at $90 \mathrm{~d}$ of gestation with dietary FA supplementation was still higher than that of the early gestation period of ewes fed the control diet. Thus, we considered the negative balance of maternal folate during the gestation period has been improved by maternal dietary FA addition.

Hcy concentrations decreased with FA supplementation in the diet compared with the control groups from 30 days of pregnancy to lambing, the decreased Hcy levels in serum are consistent with studies in dairy cows [10] and piglets [22]. Dietary folate depletion could result in an increase of serum Hcy, which could promote oxidative stress [5]. Maternal dietary FA supplementation improved serum folate concentration and decreased Hcy concentrations from gestation to lambing. Overall concentrations of folate and Hcy were consistent among all the treatments regardless of litter size and supplementary FA levels.

IGF-I and GH are of major significance in the regulation of cell metabolism, muscle development, adipogenesis, glucose, and energy metabolism [23-25]. Therefore, IGF-I and GH are valuable indicators for evaluating the animal's metabolic condition. In the current study, IGF-I concentrations in the serum increased with FA supplementation from late gestation to lambing regardless of litter size, which means FA had a positive effect on maintaining maternal metabolism. However, as gestation progressed, IGF-I levels only in the ewes fed additional FA and pregnant with triplet fetuses increased linearly. We speculated that this might be due to dietary FA supplementation maintaining maternal and fetal nutrients metabolism by regulating maternal IGF-I levels to satisfy the higher requirement of nutrients for ewes pregnant with three fetuses. In addition, maternal serum IGF-I also plays a key role in enhancing the placental function in sheep [26], while folate is critical in modulating placental nutrient transport and fetal growth [27]. Thus, it is likely that FA influences the fetus's development by regulating maternal IGF-I levels to stimulate placental efficiency, which deserves further study.

GH was not affected by litter size or dietary FA supplementation, and the linear increase of GH from early gestation to lambing in the ewes pregnant with twins with FA supplementation and the ewes pregnant with triplets. Maternal GH concentrations increased as gestation progressed presumably to modulate the growth of the fetus [28].

We also considered the effect of FA on immunity because of its critical role on health. Supplementary FA enhances the immune system in aquatic animals [6,29] and humans [30]. The increased immunoglobulin in maternal serum offer FA supplementation in the perinatal period could contribute to promoting the ewe's immunity during perinatal period and postpartum recovery. From early gestation to lambing, the increase of IgG in both TW and TR ewes indicated the ewe's immunity was positively affected by dietary FA levels during pregnancy. Results in human (long-term synthetic FA supplementation) [30] and broiler (in ovo injection of FA) [31] also showed FA supplementation was beneficial to immune function. IgM only increased in TR ewes treated with FA addition, the lack of response by TW ewes during gestation remains unclear and is deserving of further research.

There is a close relationship between milk composition and blood constituents [32,33]. In the present study, folate concentrations in colostrum increased with dietary FA supplementation during gestation. It is possible that the increasing blood folate from late gestation to lambing may contribute to the preparation of the mammary gland for lactation. Girard et al. (2005) reported that folate concentration in milk of cows showed a quadratic response to different dietary FA supplementation, and this may be because milk folate secretion is regulated by the mammary gland [34]. In the current study, milk folate concentration at day 15 of lactation was still higher in ewes with FA supplementation than CON ewes. This means maternal FA supplementation during pregnancy has a long-term influence on milk folate concentration. 
Colostrum is a nutrient-rich source with complex biological components and contributes to the initial acquired immunity of neonates [35]. Colostrum IgG as the major immunoglobulin involved in stimulating the maturation of the newborn's immune system [36]. Lactoferrin not only plays a role as an iron-binding protein with bacteriostatic properties, but also works as a host defense mechanism against microbial infection [37]. The IgG and lactoferrin content in both colostrum and milk increased with dietary FA supplementation, which means maternal FA supplementation during pregnancy may contribute to the immunity of newborn lambs. With FA supplemented in the diet, the increased IgG content in the colostrum and milk consist with the variance of serum IgG concentrations in the late gestation and lactation, and previous study demonstrated the positive relationship of IgG concentrations between the ewe's serum and colostrum [38]. We also found IgG content in colostrum was higher in TW than TR. This may be explained by the litter size having a positive relationship with milk production [39] and milk production having a negative relationship with milk components [40]. Compared with colostrum, IgG and lactoferrin content were decreased in milk at day 15 of lactation. Ewes with triplets produced milk with higher concentration of lactoferrin. We suspect that mothers with a larger litter size could stimulate more lactoferrin secretion to protect the newborn lambs against bacteria and viruses from the environment to ensure better survival of their offspring.

Folic acid is an essential nutrient for protein synthesis, and contributes to the optimization of milk quality [20]. For multiparous cows, folic acid injection or dietary supplementation increases milk protein $[34,41]$. In our study, the protein content in colostrum also increased with FA supplemented in the diet during pregnancy, and showed a tendency to contain more protein in milk at day 15 of lactation. It is hypothesized that FA supplementation influences lactation performance by changing the regeneration of methionine from homocysteine, thereby regulating the milk protein [34]. Other studies suggest supplementary FA may modulate lactational performance by improving energy balance [10] or energy metabolism [41]. In addition, Sacadura et al. (2008) reported that vitamin B supplementation increased milk and milk component yields probably due to improved metabolic efficiency of intermediary metabolism [42].

Therefore, FA supplementation during gestation could contribute to maternal blood metabolic and improve milk quality, which suggested its benefit for the growth and development of offspring $[43,44]$. Moreover, more research is needed to investigate maternal nutrient digestion and transport with FA supplementation during gestation, and milk quality affected by FA supplementing in lactation diet, especially in high prolific breeds.

\section{Conclusions}

Our results indicate dietary folic acid supplementation increases serum folate concentration to improve folate metabolism balance during the gestation period of prolific ewes. Moreover, the various Hcy, IGF-I, GH, and immunoglobulin concentrations influenced by supplementary folic acid in the diet and gestation progress, especially in the ewes with triplet litters and in the period from late gestation to parturition, suggest folic acid may contribute to pregnant ewes metabolism and health. In addition, supplementary folic acid improved the quality of colostrum and milk by modifying their concentrations of folate, lactoferrin, $\mathrm{IgG}$, and protein.

Author Contributions: Formal analysis, B.W., H.L. (Heqiong Li), and H.L. (Hailing Luo); methodology, Z.L., H.L. (Heqiong Li), and H.L. (Hailing Luo); data curation, B.W., Z.L., H.L. (Heqiong Li), L.J., and Z.D.; project administration, B.W. and H.L. (Hailing Luo); writing-original draft preparation, B.W.; writing-review and editing, H.L. (Hailing Luo) and H.T.B. All authors have read and agreed to the published version of the manuscript.

Funding: This research was funded by the National Key Research and Development Program of China (Grant number: 2018YFD0500402) and China Agriculture Research System (Grant number: CARS-38).

Acknowledgments: The authors would like to acknowledge the support of the National Key Research and Development Program of China (2018YFD0500402) and China Agriculture Research System (CARS-38) for this work.

Conflicts of Interest: The authors declare that there are no conflict of interest. 


\section{References}

1. Fekete, K.; Berti, C.; Trovato, M.; Lohner, S.; Dullemeijer, C.; Souverein, O.W.; Cetin, I.; Decsi, T. Effect of folate intake on health outcomes in pregnancy: A systematic review and meta-analysis on birth weight, placental weight and length of gestation. Nutr. J. 2012, 11, 75. [CrossRef]

2. Bailey, L.B.; Gregory, J.F. Folate metabolism and requirements. J. Nutr. 1999, 129, 779-782. [CrossRef] [PubMed]

3. Wagner, C. Biochemical role of folate in cellular metabolism (Reprinted from Folate and Health Disease, pp 23-42, 1995). Clin. Res. Regul. Aff. 2001, 18, 161-180. [CrossRef]

4. Chou, Y.; Yu, C.; Huang, R.S. Changes in mitochondrial DNA deletion, content, and biogenesis in folate-deficient tissues of young rats depend on mitochondrial folate and oxidative DNA injuries. J. Nutr. 2007, 137, 2036-2042. [CrossRef] [PubMed]

5. Huang, R.; Hsu, Y.C.; Lin, H.L.; Yang, F.L. Folate depletion and elevated plasma homocysteine promote oxidative stress in rat livers. J. Nutr. 2001, 131, 33-38. [CrossRef]

6. Asaikkutti, A.; Bhavan, P.S.; Vimala, K. Effects of different levels of dietary folic acid on the growth performance, muscle composition, immune response and antioxidant capacity of freshwater prawn, Macrobrachium rosenbergii. Aquaculture 2016, 464, 136-144. [CrossRef]

7. Girard, C.L. B-complex vitamins for dairy cows: A new approach. Can. J. Anim. Sci. 1998, 78S, 71-90.

8. Girard, C.L.; Matte, J.J.; Tremblay, G.F. Gestation and lactation of dairy-cows-A role for folic-acid. J. Dairy Sci. 1995, 78, 404-411. [CrossRef]

9. Graulet, B.; Matte, J.J.; Desrochers, A.; Doepel, L.; Palin, M.F.; Girard, C.L. Effects of dietary supplements of folic acid and vitamin B-12 on metabolism of dairy cows in early lactation. J. Dairy Sci. 2007, 90, 3442-3455. [CrossRef]

10. Li, H.Q.; Liu, Q.; Wang, C.; Yang, Z.M.; Guo, G.; Huo, W.J.; Pei, C.X.; Zhang, Y.L.; Zhang, S.L.; Wang, H.; et al. Effects of dietary supplements of rumen-protected folic acid on lactation performance, energy balance, blood parameters and reproductive performance in dairy cows. Anim. Feed Sci. Tech. 2016, 213, 55-63. [CrossRef]

11. Girard, C.L.; Castonguay, F.; Fahmy, M.H.; Matte, J.J. Serum and milk folates during the first two gestations and lactations in Romanov, Finnsheep, and Suffolk ewes. J. Anim. Sci. 1996, 74, 1711-1715. [CrossRef] [PubMed]

12. Piccione, G.; Casella, S.; Lutri, L.; Vazzana, I.; Ferrantelli, V.; Caola, G. Reference values for some haematological, haematochemical, and electrophoretic parameters in the Girgentana goat. Turk J. Vet. Anim. Sci. 2010, 34, 197-204.

13. Sripad, K.; Shrikant, K.; Raju, M. Hematological profile of Khillar breed of cattle in Karnataka. Veterinary World. 2014, 7, 311-314. [CrossRef]

14. Weaver, D.M.; Tyler, J.W.; VanMetre, D.C.; Hostetler, D.E.; Barrington, G.M. Passive transfer of colostral immunoglobulins in calves. J. Vet. Intern. Med. 2000, 14, 569-577. [CrossRef] [PubMed]

15. NRC. Nutrient Requirements of Small Ruminants; The National Academies Press: Washington, DC, USA, 2007.

16. AOAC Official. Official Methods of Analysis of the Association of Official Analytical Chemist, 16th ed.; AOAC, International: Gaithersburg, MD, USA, 1999.

17. Van Soest, P.J.; Robertson, J.B.; Lewis, B.A. Methods for dietary fiber, neutral detergent fiber, and nonstarch polysaccharides in relation to animal nutrition. J. Dairy Sci. 1991, 74, 3583-3597. [CrossRef]

18. Clifford, A.J.; Heid, M.K.; Muller, H.G.; Bills, N.D. Tissue distribution and prediction of total-body folate of rats. J. Nutr. 1990, 120, 1633-1639. [CrossRef]

19. Duplessis, M.; Lapierre, H.; Pellerin, D.; Laforest, J.P.; Girard, C.L. Effects of intramuscular injections of folic acid, vitamin B12, or both, on lactational performance and energy status of multiparous dairy cows. J. Dairy Sci. 2017, 100, 4051-4064. [CrossRef]

20. Girard, C.L.; Matte, J.J. Dietary supplements of folic acid during lactation: Effects on the performance of dairy cows. J. Dairy Sci. 1998, 81, 1412-1419. [CrossRef]

21. Girard, C.L.; Castonguay, F.; Matte, J.J. Response of serum concentrations of folates to dietary supplements of folic acid given to ewes during gestation. Can. J. Anim. Sci. 1999, 79, 387-389. [CrossRef]

22. Liu, J.; Yao, Y.; Yu, B.; Mao, X.; Huang, Z.; Chen, D. Effect of folic acid supplementation on hepatic antioxidant function and mitochondrial-related gene expression in weanling intrauterine growth retarded piglets. Livest. Sci. 2012, 146, 123-132. [CrossRef] 
23. Blüher, S.; Kratzsch, J.; Kiess, W. Insulin-like growth factor I, growth hormone and insulin in white adipose tissue. Best. Pract. Res. Cl. En. 2005, 19, 577-587. [CrossRef] [PubMed]

24. Clemmons, D.R. Role of IGF-I in skeletal muscle mass maintenance. Trends Endocrinol. Metab. 2009, 20, 349-356. [CrossRef] [PubMed]

25. McMurtry, J.P. Nutritional and developmental roles of insulin-like growth factors in poultry. J. Nutr. 1998, 128S, 302S-305S. [CrossRef] [PubMed]

26. Liu, L.; Harding, J.E.; Evans, P.C.; Gluckman, P.D. Maternal insulin-like growth-factor-I infusion alters fetus placental carbohydrate and protein-metabolism in pregnant sheep. Endocrinology 1994, 135, 895-900. [CrossRef]

27. Rosario, F.J.; Nathanielsz, P.W.; Powell, T.L.; Jansson, T. Maternal folate deficiency causes inhibition of mTOR signaling, down-regulation of placental amino acid transporters and fetal growth restriction in mice. Sci. Rep-UK. 2017, 7, 3982. [CrossRef]

28. Lassarre, C.; Hardouin, S.; Daffos, F.; Forestier, F.; Frankenne, F.; Binoux, M. Serum insulin-like growth factors and insulin-like growth factor binding proteins in the human fetus. Relationships with growth in normal subjects and in subjects with intrauterine growth retardation. Pediatr. Res. 1991, 29, 219-225. [CrossRef]

29. Wei, J.J.; Zhang, F.; Tian, W.J.; Kong, Y.Q.; Li, Q.; Yu, N.; Du, Z.Y.; Wu, Q.Q.; Qin, J.G.; Chen, L.Q. Effects of dietary folic acid on growth, antioxidant capacity, non-specific immune response and disease resistance of juvenile Chinese mitten crabEriocheir sinensis (Milne-Edwards, 1853). Aquaculture 2016, 22, 567-574. [CrossRef]

30. Duthie, S.J.; Horgan, G.; de Roos, B.; Rucklidge, G.; Reid, M.; Duncan, G.; Pirie, L.; Basten, G.P.; Power, H.J. Blood Folate Status and Expression of Proteins Involved in Immune Function, Inflammation, and Coagulation: Biochemical and Proteomic Changes in the Plasma of Humans in Response to Long-Term Synthetic Folic Acid Supplementation. J. Proteome Res. 2010, 9, 1941-1950. [CrossRef]

31. Li, S.; Zhi, L.; Liu, Y.; Shen, J.; Liu, L.; Yao, J.; Yang, X. Effect of in ovo feeding of folic acid on the folate metabolism, immune function and epigenetic modification of immune effector molecules of broiler. Brit. J. Nutr. 2016, 115, 411-421. [CrossRef]

32. Hassan, G.A.; Elnouty, F.D.; Samak, M.A.; Salem, M.H. Relationship between milk production and some blood constituents in egyptian baladi goats. Beiträge Zur Tropischen Landwirtschaft Und Veterinärmedizin 1986, 24, 213-219.

33. Bahiram, K.B.; Khan, J.R.; Korde, J.P. Correlation between Milk Production Traits, Certain Hormones and Serum Biochemical Parameters in Lactating Murrah Buffaloes. Indian J. Vet Sci. Biotech. 2018, 13, 61-64.

34. Girard, C.L.; Lapierre, H.; Matte, J.J.; Lobley, G.E. Effects of dietary supplements of folic acid and rumen-protected methionine on lactational performance and folate metabolism of dairy cows. J. Dairy Sci. 2005, 88, 660-670. [CrossRef]

35. Uruakpa, F.O.; Ismond, M.; Akobundu, E. Colostrum and its benefits: A review. Nutr. Res. 2002, $22,755-767$. [CrossRef]

36. Stelwagen, K.; Carpenter, E.; Haigh, B.; Hodgkinson, A.; Wheeler, T.T. Immune components of bovine colostrum and milk. J. Anim. Sci. 2009, 87, 3-9. [CrossRef]

37. Ward, P.P.; Paz, E.; Conneely, O.M. Multifunctional roles of lactoferrin: A critical overview. Cell Mol. Life Sci. 2005, 62, 2540-2548. [CrossRef]

38. Vatankhah, M. Relationship between immunoglobulin concentrations in the ewe's serum and colostrum, and lamb's serum in Lori-Bakhtiari sheep. Iranian J. Appl. Anim. Sci. 2013, 3, 539-544.

39. Rosales Nieto, C.A.; Ferguson, M.B.; Macleay, C.A.; Briegel, J.R.; Wood, D.A.; Martin, G.B.; Bencini, R.; Thompson, A.N. Milk production and composition, and progeny performance in young ewes with high merit for rapid growth and muscle and fat accumulation. Animal 2018, 12, 2292-2299. [CrossRef]

40. Bencini, R.; Pulina, G. The quality of sheep milk: A review. Aust. J. Exp. Agr. 1997, 37, 485-504. [CrossRef]

41. Preynat, A.; Lapierre, H.; Thivierge, M.C.; Palin, M.F.; Cardinault, N.; Matte, J.J.; Desrochers, A.; Girard, C.L. Effects of supplementary folic acid and vitamin B (12) on hepatic metabolism of dairy cows according to methionine supply. J. Dairy Sci. 2010, 93, 2130-2142. [CrossRef]

42. Sacadura, F.C.; Robinson, P.H.; Evans, E.; Lordelo, M. Effects of a ruminally protected B-vitamin supplement on milk yield and composition of lactating dairy cows. Anim. Feed Sci. Tech. 2008, 144, 111-124. [CrossRef] 
43. Wang, B.; Li, H.Q.; Li, Z.; Jian, L.Y.; Gao, Y.F.; Qu, Y.H.; Liu, C.; Xu, C.C.; Li, Y.X.; Diao, Z.C.; et al. Maternal folic acid supplementation modulates the growth performance, muscle development and immunity of $\mathrm{Hu}$ sheep offspring of different litter size. J. Nutr. Biochem. 2019, 70, 194-201. [CrossRef] [PubMed]

44. Li, H.Q.; Wang, B.; Li, Z.; Luo, H.L.; Wang, Y.J.; Zhang, C.; Jian, L.Y.; Gao, Y.F.; Lu, W.; Liu, M.; et al. Effects of rumen-protected folic acid addition in maternal and post-weaning diets on growth performance, total tract digestibility, ruminal fermentation and blood metabolites in lambs. Anim. Feed Sci. Tech. 2020, 260, 114364. [CrossRef]

(C) 2020 by the authors. Licensee MDPI, Basel, Switzerland. This article is an open access article distributed under the terms and conditions of the Creative Commons Attribution (CC BY) license (http://creativecommons.org/licenses/by/4.0/). 